\title{
MODEL OF MARKETING COMMUNICATIONS EFFECTIVENESS IN THE BUSINESS-TO-BUSINESS MARKETS
}

\author{
Damjana Jerman* $\quad$ Bruno Zavrsnik ${ }^{\dagger}$ \\ Keywords: Marketing communication effectiveness, \\ business-to-business markets, marketing communication objectives, \\ organizational performance, structural equation modelling \\ JEL: M31
}

\begin{abstract}
Much of the research into marketing communications has focused on the consumer market with little regard to date for the business-to-business market. This paper focuses on a development and testing of a model of marketing communication effectiveness in the business-to-business market. Building on past research from the marketing communications and business-to-business marketing literature, the model (which incorporates facets of the marketing communication objectives, bidirectional communications, and communications channels) is tested to examine the impact
\end{abstract}

*University of Primorska, Faculty of Tourism Studies, Obala 11a, 6320 Portorož, Slovenia, Phone: +3865 40285787, Fax: +386 561770 20, E-mail address: damjana.jerman@turistica.si

†University of Maribor, Faculty of Economics and Business, Razlagova 20, 2000 Maribor, Slovenia, Phone: +386 2 2290292, Fax: +386 22527 056, E-mail address: bruno.zavrsnik@uni-mb.si 


\begin{abstract}
of these antecedent variables on marketing communications effectiveness and organizational performance. The concept of marketing communication effectiveness assumes that there are variables that can have a positive influence on the effectiveness of marketing communications, and confirm the central concept of marketing communication effectiveness as having a positive impact on organizational performance. Managerial implications are discussed along with suggestions for further research.
\end{abstract}

\title{
1 INTRODUCTION
}

This paper focuses on a new model for marketing communication effectiveness in the business-to-business context. Any company can develop a marketing communication program, regardless of budget or staff size. The key to implementing a successful program, however, is to incorporate measurement and analysis right from the beginning of marketing communication programme (Jerman, 2007, 871).

In recent years, the business-to-business marketing has experienced significant progress due to a number of theoretical and empirical findings published in the journals that examined the business-to-business market. A number of authors have written about the role and importance of marketing communications in the industrial markets (Smith, Gopalakrishna, Smith, 2004, 61; Garber, Dotson, 2002, 1; Rinallo, Borghini, 2003, 20; Kitchen, Schultz, 2003, 66; Wickham, Hall, 2006, 95; Hall, Wickham, 2008, 139). However, marketing communication in the business-to-business markets offers further potentially valuable opportunities of research, especially empirical research.

With the increasing call for accountability of significant marketing communication spending, measuring the contribution of marketing communication effectiveness to firm performance is inevitable and valued (Kitchen, Schultz, 2009, 201; placeEwing, 2009, 104; Rust et al., 2004, 76). However, measuring marketing communication impact on organizational performance has historically proven to be difficult, if not impossible. Benkahla $(2006,10)$ argues that integrated marketing communications still has no standard form for testing its

Damjana Jerman, Bruno Zavrsnik - MODEL OF MARKETING 
effectiveness. Reid, Luxton and Mavondo $(2005,18)$ argue that the problem associated with such performance measure for marketing is the conceptualization of marketing inputs. Marketing communications results have historically been measured on a medium-by-medium basis: One measure for advertising, another for publicity, still another for sales promotion, and so on (placeEwing, 2009, 104). These issues regarding the measurability of marketing communication programmes have also been a focus of discussion among academics and practitioners since the early stages of the development of the integrated marketing communications concept (Kliatchko, 2009, 157).

In recognizing this complexity, this paper attempts to explain the effect of different factors on marketing communication effectiveness and subsequently on organizational performance. We hypothesize that a company's marketing communications effectiveness generates favourable organizational performance in Slovenian companies. In this context, we explore marketing communications effectiveness and how this effectiveness can influence organizational performance of selected firms. A firm should have a business model that tracks how marketing communications effectiveness influences what its customers know, believe, and feel, and ultimately of course how they behave.

Another contribution of this paper is that it tests the model of marketing communications effectiveness within a nomological net of antecedents and consequences. A unique contribution is an examination of the effect of marketing communication effectiveness on performance measure; we include such outcomes as market and financial performance when assessing the effect of marketing communication effectiveness on a firm. By adopting this approach, we offer a framework to other managers for how to enhance the effectiveness of their marketing communications. In terms of contributions, this model provides managers a priori basis for focusing their efforts on the antecedents of whole marketing communications effectiveness which produces a much higher effect on organizational performance.

First, we present a review of the literature, drawing on marketing communications effectiveness theory and business-to-business market theory, and past research to develop our model. Second, our hypotheses are developed and dis- 
cussed. Third, the procedures for testing these hypotheses are described, followed by a presentation of study results. Finally, we discuss the implications of the research and conclude with future research directions.

\section{LITERATURE REVIEW}

The literature offers limited empirical and theoretical insight into marketing communications effectiveness in business-to-business marketing. Specifically, there is little help for marketing communications managers when planning effective communications strategies and understanding their impact on organizational performance. We build on these gaps by exploring different factors that can impact marketing communications effectiveness, including the effects of these factors on actual market performance.

Business-to-business customers behave differently, are motivated by different criteria, and buy differently. The literature suggests that selling to business buyers is much different than selling to end consumers. The business customer is usually more knowledgeable and seeks more information, and the products and services offered to business customers are usually more complex. The differences between industrial or business-to-business marketing and consumer marketing are not in the concept, nor indeed in their value or relevance. Rather the differences are found in the techniques employed, the nature and complexity of purchasing decision-making, and the size of the budgets available for achieving these objectives. It has been posited that different instruments used in marketing communications' targeting business customers play more of an informational and supportive role than do those marketing communications that target final or end consumers (Grove, Carlson, Dorsch, 2007, 39; Tosun, 2003, 2).

The particularities of marketing communications in the business-to-business markets are evident, especially in the composition of a marketing communication mix, which will depend on various market factors. A relatively small number of participants and the complexity of purchasing decisions in businessto-business markets usually require more involvement and the least disturbed two-way exchange of information. In the case of complex technical products and 
services, where several persons are involved in the purchase and decision-making process, interpersonal communication is the best way to present such products or services and their properties.

Since there is two-way communication involved, the seller may hold the buyer's response to the perception of that product/marketing information; to adapt and keep this process eliminates any confusion or doubt. This process was adapted to the choice of ways to deliver marketing communication, among which is the domination of by direct personal contact. Throughout the marketing communication mix in the industrial market, the sales staff has the biggest influence on customer attitudes. The buyer in the business-to-business markets prefers communication tools that allow a direct and interactive exchange of information like direct mail, fairs, conferences, and visits of sales representatives (Tosun, 2003, 3; Borghini, Rinallo, 2003, 6). However, there exists limited literature that explores marketing communication in the business-to-business context (Nowak, Cameron, Delorme, 1996, 173; McArthur, Griffin, 1997, 19; Low, 2000, 27; Garber, Dotson, 2002, 1; Kitchen, Schultz, 2003, 66; Hall, Wickham, 2008, 193; Grove, Carlson, Dorsch, 2007, 37-54).

The literature on marketing communications is broadly made up of a body of literature related to Integrated Marketing Communications (IMC), as firms have become interested in integrating their marketing communications for better results. IMC is one of the most debated topics in the current marketing communications literature. That literature contains a number of research studies that focus on a variety of issues. For example, Herrington et al. (1996, 61 ), measured attitudes and the use of integrated marketing communications in services as compared to those for non-service industries. Gould $(1999,7)$ and Kitchen $(1999,21)$ surveyed multinational advertising agencies on their use of integrated marketing communications for global customers. Low $(2000,27)$ surveyed different types of organizations to determine which are most likely to employ an integrated marketing communications strategy. Reid et al. (2001, 239) surveyed wineries to determine whether the brand associated with implementation differed for those firms that undertake an integrated marketing communications strategy. In summary, two points emerge from an examination 
of the existing research on integrated marketing communications. First, there is a lack of available research designed for testing integrated marketing communications in a business-to-business context. Second, there is a general agreement that much more research in this area is needed.

To the extent that marketing communication can be influenced by different factors through constructs, it is important for marketers to understand the collective contribution of those factors to the overall effectiveness of their marketing communications.

\section{CONCEPTUALISATION OF MARKETING COMMUNICATION EFFECTIVENESS AND ITS RELATED CONSTRUCTS}

Interactions that occur among marketing communications variables form an important aspect of our understanding of marketing communication effectiveness overall. The effectiveness of marketing communications has been examined by innumerable authors (Schultz, Patti, 2009, 81; Evans, Fill, 2000, 391; Rust et al., 2004, 77; Smith, Gopalakrishna, Chatterjee, 2006, 564; Žabkar, 2007, 83). In order to develop further investigation in this research area, it is necessary to adopt first a perspective for defining actual marketing communication effectiveness and its associated $\mathrm{r}$ concepts. Next, it is necessary to identify or, alternatively, develop a valid, reliable measurement scale to use to evaluate these proposed concepts.

In justifying and presenting our proposed model, the following five concepts were conceptualized for the purpose of Structural Equation Modelling (SEM) application in the context of marketing communications effectiveness in a businessto-business context: Marketing communication objectives, bidirectional communication, communication channels, marketing communications effectiveness, and organizational performance. We also highlighted the various approaches to conceptualizing these concepts and identified the linkages between them.

Damjana Jerman, Bruno Zavrsnik - MODEL OF MARKETING

COMMUNICATIONS EFFECTIVENESS IN THE

BUSINESS-TO-BUSINESS MARKETS 


\subsection{MARKETING COMMUNICATION OBJECTIVES}

Properly configured objectives of marketing communications will have a positive impact on effectiveness. This presumption is clear from the objectives of the integrated approach, as developed by Fisher, Maltz, Jaworski (1997, 56-57) and is based on the coordination behaviour of individuals and groups within an organization with a view toward achieving the identified objectives. The approach is also based on cooperation and interaction between the groups. Effective marketing communications is the result of coordinated operation between the functions of an organization and its chosen strategy of marketing communication resulting from both strategic goals and business strategy organization (Kliatchko, 2009, 177; Reid, 2003, 233). These correlations conclude that the development of marketing communication objectives and coordination with firm business strategy can lead to a consistent and workable strategy of marketing communication.

A strategy of marketing communication should be in line with the vision, strategy, and mission of the organization (Fill, 1999, 604) and in line with the chosen market strategy (Duncan, Moriarty, 1998, 2). Results of some studies demonstrate the positive impact of the mission of an organization on its financial performance.

For effective marketing communications, it is necessary that there be consistency among all communication messages, so that trust can be built and there can be coherence in target audience perceptions. The key to managing the point of perception is to deliver and receive messages on a platform of strategic consistency (Kitchen, Schultz, 2003, 82). In line with market orientation, the sharing of information across departments, the involvement of all departments in the preparation of business plans and strategies, the interactions of marketing personnel with other departments, are the needed prerequisites for best interfunctional coordination (Ride, Luxton, Mavondo, 2005, 15). Therefore, we hypothesize that:

H1: Marketing communication objectives positively associate with marketing communications effectiveness. 


\subsection{BIDIRECTIONAL COMMUNICATION}

Numerous studies have emphasized the role of high involvement in the communication message and its impact on changes in customer attitudes toward certain brands. The elaboration likelihood model for processing that information emphasizes the ability of communication to process and the motivation for processing the determined communication message. In order to initiate certain stimuli at the customer, the communication messages may differ both in content, which can be informative or emotional nature, and design and creative communication strategy (Brengman, Geuens, De Pelsmacker, 2001, 231).

IMC has traditionally been identified as persuasion, which entails primarily a one-way communication mode (Spotts et al., 1998, 210). In marketing relationships, however, communication serves other roles other than just persuasion, including informing, listening, and answering, which can require interaction and two-way communication forms (Finne, Grönroos, 2009, 180). The increasing importance of communication in today's marketplace is demonstrated by its ability to manage two-way communication.

An important part of any communication model is feedback, through which the receiver's response is made known to the sender (Duncan, Moriarty, 1998, 4). Marketing communications also need to provide clarity and fast, pertinent, timely information, so decisions can be made. Effective marketing communication occurs when the consumer can correctly interpret the initial message as it was meant to be sent. This bidirectional communication produces effective marketing communications. Bidirectional communication is thus hypothesized as being positively related to marketing communications effectiveness. Therefore, we hypothesize that:

H2: Bidirectional communication positively associates with marketing communication effectiveness.

\subsection{COMMUNICATION CHANNELS}

The marketing communication channel, which views human communication as a transmission process during which a message travels across a channel from 
a sender to a receiver, is represented by the communication dimensions of frequency and mode of communication (Goebel, Marshall, Locander, 2004, 32). Communication frequency refers to the amount of communication that occurs between an organization and its public (Schultz, Patti, 2009, 81-82). Communication mode is defined as the channel, formal or informal, through which such information is transmitted to target groups (Maltz, Kohli, 1996, 47; Mohr, Sohi, 1995, 393). Previous research has found that information disseminated in a formal manner is seen as more credible (Mohr, Sohi, 1995, 393).

Marketing communication channels are hypothesized to be positively related to marketing communication effectiveness. Therefore, we hypothesize that:

H3: Marketing communication channels positively associate with marketing communication effectiveness.

\subsection{MARKETING COMMUNICATION EFFECTIVENESS}

A study conducted by Low $(2000,31)$ showed that implementing IMC (Integrated Marketing Communication) may be strongly related to better marketing results in terms of sales, market share, and profits for an organisation. In seeking to understand the effectiveness of marketing communications, researchers have traditionally relied on measures of awareness, recall, and recognition (Beerli, Santana, 1999, 11).

Many researchers, through their theoretical and empirical contributions, describe the impact of marketing communications on organization performance, particularly with a view to improving relations between the organization and its public, for example, its customers (McGoon, 1998, 15; Low, 2000, 36). Explanation of this relation can be found in the degree of marketing communication effectiveness and its impact on overall organizational performance (Kitchen, Schultz, 2009, 201; Young, Aitken, 2007, 53).

Reid $(2005,41-47)$ in a research model displays a potential way of measuring and evaluating the implementation of IMC. The results of his research show a strong and significant positive impact of the performance of IMC on market performance. The relationship between the marketing communication and organizational performance is an important area of research, but only a few 
empirical studies have supported this link (Cornelissen, Lock, 2000, 7-15, Low, 2000, 27-39).

An organization that possesses marketing communication capabilities can create successful communication programs and ensure long-term market performance. There is a positive impact between possessing strong marketing communication capabilities and organizational performance

(Ewing, 2009, 111-112).

The success of an organization can also result from the effectiveness of its marketing communication. In this area, many authors highlight the positive impact of marketing communications on organization performance (Ewing, 2009, 103; Schultz, Kitchen, 1997, 7; Low, 2000, 36; Pickton, Broderick, 2001, 3). So, we hypothesize that:

H4: Marketing communications effectiveness positively associate with organizational performance.

\subsection{ORGANIZATIONAL PERFORMANCE}

In order to evaluate the organizational performance of the respondents' firms in this study, we employed some of the subjective measures more frequently used in other investigations, such as return on investment, profits, and sales (Le Meunier-FitzHugh, Lane, 2009, 291; Langerak, Commandeur, 1998, 91; Avlonitis, Gounaris, 1997, 385). Respondents were asked to indicate the evolution, in the last period, of the mentioned variables relative to a company's objectives (Avlonitis, Gounaris, 1997, 390). Organizational performance can be measured by both subjective and objective indicators.

Subjective indicators are based on the subjective assessment of a company's performance in comparison with its competitors, with planned results compared to those for the previous period, etc. Objective performance indicators are based on official data from the financial statements of a company. Dess and Robinson (1984, 265) and Hansen and Wenerfelt $(1989,399)$ proved there are correlations between subjective and objective indicators of business performance.

Market performance is typically related to market communication effectiveness expenditures for such variables as market share and sales. Marketing commu- 
nication effectiveness can influence a firm's market share and sales, thereby influencing its competitive market position (Rust et al., 2004, 79).

While achieving improved sales and market share is essential to any marketing communication effort, many firms consider financial impact the most crucial measure of success for any marketing communication activity. Financial benefits from marketing communication effectiveness can be evaluated in several ways. Return on investment (ROI) is a traditional approach to use to evaluate return relative to the expenditure required to obtain that return. Financial performance involves an increase in revenues (Rust et al., 2004, 2).

\section{RESEARCH DESIGN}

\subsection{SAMPLE AND DATA COLLECTION PROCEDURES}

The main research instrument for empirical investigation in this study, e.g. a questionnaire, was developed on a derived theoretical basis. Cover letters with questionnaires were mailed to corporate directors, marketing directors or directors of 1000 Slovenian enterprises. We choose the convenience sample. The survey was conducted in 2008. We determined there were 59 nondeliverable and non-compliance questionnaires (e.g. incorrect address, respondents reported they wouldn't respond to surveys). A total of 269 (210 usable) returned questionnaires represented a of $22,3 \%$ response rate, which was quite satisfactory, given that average top management survey response rate in business-to-business markets is approximately 15\% (Malhotra, Birks, 2003; quoted in Wilkinson, Young, 2004, 577). The results presented in this paper relate to the final sample of 210 respondents. The collected empirical data were processed with LISREL and SPSS.

The relevant data of the companies were provided mainly by marketing directors (28,6\% of cases), followed by company directors or presidents of the managing board with $28,1 \%$, members of top management (19,0\%), business consultants $(9,0 \%)$ and head executives $(5,7 \%)$. Heads of public relations offices or heads 
of marketing and public relations offices answered at 7,2\% and counselling specialists answered at 2,4\%.

Company size was determined in terms of number of employees. The sample consisted of 45,2 \% small companies, 23,8 \% mid- sized companies and 31,0\% large companies. The companies included in the sample were distributed according to industries as follows: $42,4 \%$ of respondents belonged to productionoriented companies; $30,4 \%$ of respondents belonged to service- oriented companies; and $24,3 \%$ were trade- oriented companies. The sample included of $2,4 \%$ institutions and 0,5\% government organizations.

\subsection{MEASURES OF THE VARIABLES}

The scales utilized for this study are taken from the literature in marketing communications and a business performance context with some modifications where needed to fit the current study context. All the constructs, e.g. marketing communication objectives, bidirectional communication, communication channels, marketing communication effectiveness, and organizational performance, were measured on a Likert scale. The respondents had to indicate their agreement with the statements on a 7 -point Likert (1 strongly disagree to 7 strongly agree) scale.

Below is a description and the operationalization of each measure.

\section{Marketing communication objectives}

The construct "marketing communication objectives" was operationalized as a reflective construct and measured with a 5 -item scale, consisting of items drawn from Fill $(1999,604)$ and Duncan and Moriarty $(1998,2)$.

Bidirectional communication

The construct "bidirectional communication" was also operationalized as a reflective construct and measured with a 4-item scale, consisting of items drawn from Fill $(1999,604)$ and Duncan and Moriarty $(1998,7)$.

Communication channels

The construct "Communication channels" was operationalized as a reflective construct that assessed the frequency of contact over different modes of com- 
munication. It was measured with a 2-item scale (Goebel, Marhall, Locander, 2004, 35).

Marketing communication effectiveness

Marketing communication effectiveness was operationalized as a reflective construct and measured on a 3-item scale adapted from Low (2000, 27), Young, Aitken (1999, 52-53), and Duncan, Moriarty (1998, 2).

Organizational performance

The construct »Organizational performance« was operationalized as a reflective construct and measured with a 3-item scale, consisting of items drawn from Zahay, Griffin (2004, 169), Priyanto (2006, 103), Rust et al. (2004, 76), and Boulding, Lee, and Staelin (1994, 159).

Reliability and validity issues were addressed using such methods as exploratory factor analysis, reliability analysis, and convergent validity. To test the internal consistency of the measurement scales, a reliability analysis was conducted for each distinct dimension. Except for the measurement scale for communication channels and bidirectional communication, the coefficient alphas (Cronbach, 1951) exceeded the suggested 0.80 level mentioned in the literature. Therefore, the measurement scales for marketing communication effectiveness and organizational performance demonstrated a relatively high degree of reliability (see Table 1).

TABLE 1 Reliability coefficients

\begin{tabular}{ccc}
\hline \hline Construct & $\begin{array}{c}\text { Number of } \\
\text { Items }\end{array}$ & $\begin{array}{c}\text { Cronbach's } \\
\boldsymbol{\alpha}\end{array}$ \\
\hline Marketing communication objectives & 5 & 0,8573 \\
(CTK) & & \\
Bidirectional communication (DK) & 4 & 0,7793 \\
Communication channels (KP) & 2 & 0,6673 \\
Marketing communication effectiveness & 3 & 0,8684 \\
$\quad$ (UTK) & 3 & 0,8137 \\
\hline \hline
\end{tabular}

Source: Authors calculation

A confirmatory factor analysis indicated the convergent validity of the scales: All latent variables exhibited indices above the reference values of the composite 
reliability index $\left(\rho_{c}\right)$ and the variance extracted $\left(\rho_{v}\right)$ (see Table 2). Composite reliability and variance extracted fell above the 0.7 and 0.5 thresholds, respectively, representing a high degree of shared representation of the indicators with the construct.

TABLE 2 Composite reliability index $\left(\rho_{c}\right)$ and variance extracted $\left(\rho_{v}\right)$ for the measurement model for marketing communications

\begin{tabular}{ccc}
\hline \hline Construct & $\begin{array}{c}\text { Composite } \\
\text { Reliability } \\
\text { Index }\left(\rho_{\mathrm{c}}\right)\end{array}$ & $\begin{array}{c}\text { Variance } \\
\text { Extracted } \\
\left(\rho_{\mathrm{v}}\right)\end{array}$ \\
\hline Marketing communication effectiveness \\
(UTK) & 0,885 & 0,719 \\
Organizational performance (UO) & 0,825 & 0,615 \\
Marketing communication objectives & 0,873 & 0,582 \\
(CTK) & 0,827 & 0,570 \\
Bidirectional communication (DK) & 0,676 & 0,514 \\
Communication channels (KP)
\end{tabular}

Source: Authors calculation

\subsection{THE MODEL}

Convergent validity was determined from the measurement model by examining whether each indicator's estimated loading on its posited underlying factor was large. Anderson and Gerbing (1988) suggest that parameter estimates should be high in value and t-values should be statistically significant. The measures in the resulting measurement model showed acceptable convergent validity with each measure being significantly related to its underlying factor and t-values being statistically significant (see Table 3 ).

The analysis was conducted using the LISREL program, which provides a simultaneous test of measurement models and structural model (Diamantopolous, Siguaw, 2000). Discriminant validity was established by determining that the average variance extracted from each latent variable's measure was larger than its shared variance with any other variable. The overall fit was acceptable. Analysis of the structural equation modelling showed that the model fit the data. 
Economic Research - Ekonomska Istrazivanja Vol. 25, SE 1, 2012 Page:378

Nevertheless, this model fit did not state that we could not find a more optimal structure model. Still, the overall fit was acceptable $\left(\chi^{2}=134,424 ; \mathrm{P}=0,065\right.$; $\chi^{2} / \mathrm{df}=1,21 ; \mathrm{RMSEA}=0,032 ; \mathrm{GFI}=0,930 ; \mathrm{AGFI}=0,903 ; \mathrm{NNFI}=0,983 ; \mathrm{CFI}=0,986$; $\mathrm{RMR}=0,048)$. Thus, we can state that the model of marketing communication effectiveness for the business-to-business markets is appropriate.

TABLE 3 Standardized Solutions for the Measurement Model $(\mathrm{n}=210)$

\begin{tabular}{|c|c|c|c|}
\hline Variable & $\begin{array}{l}\text { Completely } \\
\text { standardized } \\
\text { loading }\end{array}$ & $\begin{array}{l}\text { Variance } \\
\text { extracted } \\
\mathbf{R}^{2}\end{array}$ & $\begin{array}{c}\text { Cronbach } \\
\alpha\end{array}$ \\
\hline $\begin{array}{l}\xi_{1}: \text { Marketing communication objectives } \\
\text { (CTK) }\end{array}$ & & & 0,8573 \\
\hline $\begin{array}{l}\mathrm{X}_{1} \text { : Trust and support of top management } \\
\text { (ZAUPOD) }\end{array}$ & 0,724 & 0,524 & \\
\hline $\begin{array}{l}\mathrm{X}_{2} \text { : Building on the strategic objectives, vision } \\
\text { and mission (CILJI) }\end{array}$ & 0,824 & 0,678 & \\
\hline $\begin{array}{l}\mathrm{X}_{3} \text { : The centralization of implementation and } \\
\text { control of marketing communication } \\
\text { (CENTRAL) }\end{array}$ & 0,582 & 0,339 & \\
\hline $\begin{array}{l}\mathrm{X}_{4} \text { : Consistency with the marketing strategy } \\
\text { (TRZNASTR) }\end{array}$ & 0,858 & 0,737 & \\
\hline $\begin{array}{l}\mathrm{X}_{5} \text { : Consistency of communication messages } \\
\text { (USKLAJEN) }\end{array}$ & 0,794 & 0,631 & \\
\hline$\xi_{2}:$ Bidirectional communication (DK) & & & 0,7793 \\
\hline $\mathrm{X}_{6}:$ Feedback (POVRAT) & 0,845 & 0,714 & \\
\hline $\mathrm{X}_{7}$ : Enough information (INFO) & 0,696 & 0,484 & \\
\hline $\begin{array}{l}\mathrm{X}_{8}: \text { The accuracy and clarity of the } \\
\text { communication process (TOCNOST) }\end{array}$ & 0,605 & 0,366 & \\
\hline $\begin{array}{l}\mathrm{X}_{9} \text { : Understanding of communication messages } \\
\text { (RAZUMEV) }\end{array}$ & 0,847 & 0,717 & \\
\hline$\xi_{3}:$ Communication channels (KP) & & & 0,6673 \\
\hline $\begin{array}{l}\mathrm{X}_{10}: \text { The frequency of communication } \\
\text { (POGOST) }\end{array}$ & 0,637 & 0,406 & \\
\hline $\mathrm{X}_{11}:$ The mode of communication (VRSTA) & 0,787 & 0,619 & \\
\hline $\begin{array}{l}\eta_{1}: \text { Marketing communication effectiveness } \\
\text { (UTK) }\end{array}$ & & & 0,8684 \\
\hline $\mathrm{Y}_{1}:$ Demand and purchasing (POVP) & 0,892 & 0,796 & \\
\hline $\mathrm{Y}_{2}:$ Customer's response (ODZIV) & 0,912 & 0,833 & \\
\hline $\begin{array}{l}Y_{3} \text { : Customers' trust and identification with the } \\
\text { messages (ZAUPIDEN) }\end{array}$ & 0,732 & 0,537 & \\
\hline$\eta_{2}:$ Organizational performance (UO) & & & 0,8137 \\
\hline $\mathrm{Y}_{4}:$ Other aspects of effectiveness (DRUGI) & 0,710 & 0,505 & \\
\hline $\mathrm{Y}_{5}:$ Market effectiveness (TRZNI) & 0,703 & 0,494 & \\
\hline $\mathrm{Y}_{6}:$ Financial effectiveness (FINAN) & 0,920 & 0,847 & \\
\hline
\end{tabular}

Source: Authors calculation 
Economic Research - Ekonomska Istrazivanja Vol. 25, SE 1, 2012

FIGURE 1 The Path diagram for a Marketing Communications Model Effectiveness in Business-to-Business Markets

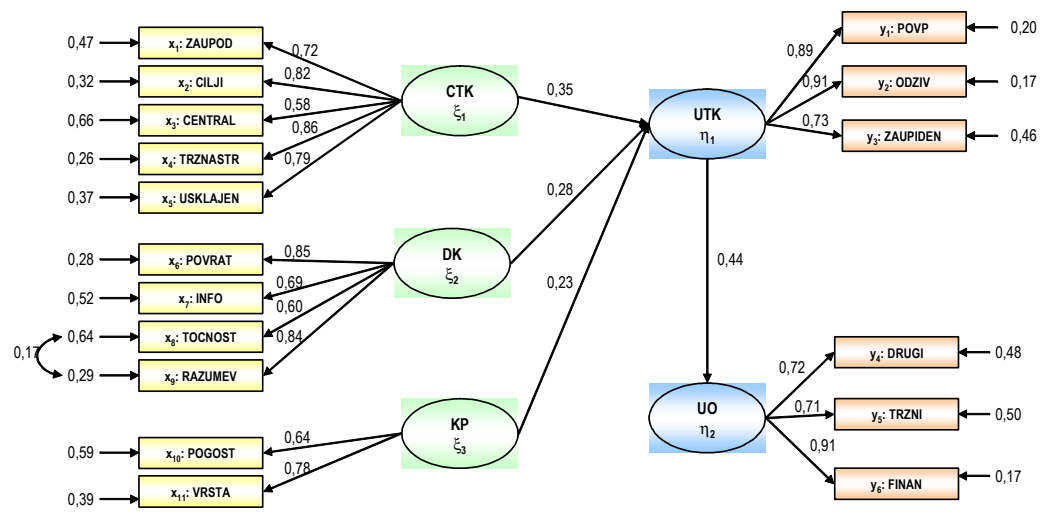

Legend:

CTK = Marketing communication objectives

$D K=$ Bidirectional communication

$K P=$ Communication channels

UTK = Marketing communication effectiveness

$U O=$ Organizational performance

Source: Authors calculation

\subsection{RESULTS AND DISCUSSION}

This study investigated only a portion of the factors that can affect marketing communication effectiveness in business-to-business markets. However, the tested model gave interesting results. To summarize, all the research hypotheses of the model, checked using the methodology for linear structural equations (SEM), were confirmed.

The analysis reveals that the domain factor that enhances marketing communication effectiveness in business-to-business markets is the achievement of marketing communication objectives. The results revealed that the construct "marketing communication objective" has a positive impact on marketing communication effectiveness (standardized coefficient $=0.35$ ) (see Figure 1). These 
findings are partly in line with the findings of Rakun $(2002,810)$ who argues that marketing communication can be a strategic function of the organization and should achieve its objectives and has an impact on the attainment of both organizational mission and vision.

As Hypothesis 2 predicted, bidirectional communication has a positive impact on marketing communication effectiveness (standardized coefficient $=0.28$ ). Duncan and Moriarty $(1998,4)$ also confirmed that feedback is an important part of a communication model through which receiver response is made known to the sender. As a result, enhanced understanding of communication messages will generate effective marketing communication.

We also found a bit weaker - but still statistically significant - positive impact between the communication channel and marketing communication effectiveness (standardized coefficient $=0.23$ ). So, Hypothesis 3 was also supported. The confirmation of this relationship will create more interest for further research in this field.

The latent variable »marketing communication effectiveness « also had a positive impact on the other endogenous variable of "organizational performance" (standardized coefficient $=0.44$ ). To summarize, Hypothesis 4 was confirmed. These results are in line with those of many other authors who have explored the impact of marketing communications on organizational performance (Kitchen, Schultz, 2009, 201; Young, Aitken, 2007, 53).

\subsection{DIRECTIONS OF FUTURE RESEARCH}

Surveys offer many opportunities for future research of organizations and how they achieve organizational performance through the effectiveness marketing communication. We tried to cover the factors that may affect the effectiveness of marketing communications, as well as empirically verify those consequences. However, there are still other opportunities to verify this conceptual model of marketing communications effectiveness. We highlighted certain factors that can impact the effectiveness of marketing communications, but at the same time we did not consider a number of external and internal factors of an organization that can affect such marketing communication. The most visible 
and profound opportunity for further research is focused on the link between marketing communication and other potential factors that may determine its effectiveness.

The interaction between individual instruments of the marketing mix (price, product, distribution, and marketing communications) and organizational performance is one of the most fundamental areas of marketing management. Decisions on marketing mix are the main components of a marketing strategy used to achieve the objectives of an organization, i.e., organizational performance. Economic science has taken a major step in studying the impact of other instruments on marketing mix, and that study can have an impact on the business performance. Yet little research has focused on the link between the precise constructs of marketing communication and organizational performance.

\section{CONCLUSION AND IMPLICATIONS}

The model of marketing communication for business-to-business markets represents a new perspective in marketing research. The central concept of the effectiveness of marketing communication assumes that there are variables that can have a positive influence on the effectiveness of marketing communication. In undertaking this study, we wanted to underline that the central area of this research is still not sufficiently studied, which forms the basis for new empirical research in this field.

However, when we talk about marketing communication to business-to-business markets, we concluded that the research area is theoretically, and in particular, also poorly studied in empirical terms (Wickham, Hall, 2006, 100; Garber, Dotson, 2002, 1-17). This is due to a lack of empirical evidence on the effectiveness of marketing communication on these business-to-business markets, which represent a conceptual model which still has not verified the significant contribution to the field that marketing communication on the business-to-business markets can make.

Further, another important theoretical contribution will be to study the area of effectiveness of marketing communication. In doing so, we came to the con- 
clusion that marketing communication objectives do have a major impact on marketing communication effectiveness and best explain success. We also found we can explain the positive impact of bidirectional communication on the effectiveness of marketing communication. The proposed positive relationship between communication channels and marketing communication effectiveness was confirmed.

A further contribution would be confirmation of the positive relationship between marketing communication effectiveness and organizational performance. Another important theoretical contribution to the field would be further study of the effectiveness of marketing communication model from a strategic point of view, namely, as a central concept of the antecedents and consequences in a model for marketing communication effectiveness on business-to-business markets.

This paper contributes to the literature by developing a structural equation model framework as a response to the call made by marketing communication researchers (Low, 2000, 27; Reid et al., 2001, 239). This call suggested the use of more exploratory research to better operationalize both the concepts of marketing communication effectiveness and organizational performance and confirm that relationship.

An important contribution to management not only results in better performance of marketing communication, but the possibility that organizations can actually measure the effectiveness of marketing communication in terms of increased response to increased demand, sales and increased trust of target groups. It is a given that measuring instruments are the basis for achieving the effectiveness of marketing communication, and consequently achieving organizational performance. With the possibility of measuring the effectiveness of marketing communication are also opportunities for greater success of organizations' operating in business-to-business markets. This contribution is important because the literature is filled with calls for more empirical research into the field of marketing communication in business-to-business markets. Designing and testing the conceptual model offered here does represent a modest first step in that direction. 
Economic Research - Ekonomska Istrazivanja Vol. 25, SE 1, 2012 Page:383

\section{REFERENCES}

Anderson, J., Gerbing D. (1988): Structural Equation Modeling in Practice: A Review and Recommended Two - Step Approach, Psychological Bulletin, Vol. 103, pp. 411-423.

Avlonitis, G., Gounaris, S. (1997): Marketing orientation and company performance: industrial versus consumer goods companies, Industrial Marketing Management, Vol. 26, No. 5, pp. 385-402.

Beerli, A., Santana, J. (1999): Design and validation of an instrument for measuring advertising effectiveness in the printed media, Journal of Current Issues and Research in Advertising, Vol. 21, No. 2, pp. 11-30.

Borghini, S., Rinallo, D. (2003): Communicating competence in the medical diagnostic industry, A customers' view? in $19^{\text {th }}$ IMP conference, http://www.impgroup.org/paper_view.php?viewPaper=4299, (accessed 23 June 2005)

Boulding, W., Lee, E., Staelin, R. (1994): Mastering the Mix: Do Advertising, Promotion, and Sales Force Activities lead to differentiation?, Journal of Marketing Research, Vol. 31, pp. 159-172.

Brengman, M., Geuens, M., De Pelsmacker, P. (2001): The impact of consumer characteristics and campaign related factors on brand confusion in print advertising, Journal of Marketing Communications, Vol. 7, pp. 231-243.

Cornelissen, J., Lock, A. (2000): Theoretical Concept or Management Fashion? Examining the Significance of IMC, Journal of Advertising Research, pp. 7-15.

Cronbach, L.J. (1951): Coefficient Alpha and Internal Structure of Tests,

Psychometrika, Vol. 16, 297-334.

Dess, G., Robinson, R. (1984): Measuring organizational performance in the absence of objecitve measures: the case of the privately firm and conglomerate business unit, Strategic management Journal, Vol. 5, No. 2, pp. 265-273.

Damjana Jerman, Bruno Zavrsnik - MODEL OF MARKETING COMMUNICATIONS EFFECTIVENESS IN THE BUSINESS-TO-BUSINESS MARKETS 
Economic Research - Ekonomska Istrazivanja Vol. 25, SE 1, 2012 Page:384

Diamantopoulos, A., Siguaw, J. (2000): Indroducing LISREL: A Guide for the Uninitiated, London: Sage Publications.

Duncan, T., Moriarty, S. (1998): A Communication - Based Marketing Model for Managing Relationships, Journal of Marketing, Vol. 62, pp. $1-13$.

Evans, M., Fill, C. (2000): Extending the communication process: the significance of the personal influencers in UK motor markets, International Journal of Advertising, Vol. 19, No. 3, pp. 377-396.

Ewing, M. (2009): Integrated marketing communications measurement and evaluation, Journal of Marketing Communications, Vol. 15, Nos. 2-3, pp. 103-117.

Finne, A., Grönroos, C. (2009): Rethinking marketing communication: From integrated marketing communication to relationship communication, Journal of Marketing Communications, Vol. 15, Nos. 2-3, pp. 179-195. Fill, C. (1999): Marketing communications: contexts, contents and strategies, London, Prentice Hall Europe.

Fisher, R., Maltz, E., Jaworski, B. (1997): Enhancing communication between marketing and engineering: the moderating role of relative functional identification, Journal of Marketing, Vol. 61, pp. 54-70.

Garber, L., Dotson, M. (2002): A method for the selection of appropriate business-to-business integrated marketing communications mixes, Journal of Marketing Communications, Vol. 8, pp. 1-17.

Goebel, D., Marshall, G., Locander, W. (2004): An organizational communicationbased model of individual customer orientation of nonmarketing members of a firm, Journal of Strategic Marketing, Vol. 12, pp. 29-56.

Gould, S. (1999): Agency perceptions and practices on global IMC, Journal of Advertising Research, Vol. 39, No. 1, pp. 7-20.

Grove, S., Carlson, L., Dorsch, M. (2007): Comparing the application of integrated marketing communication (IMC) in magazine ads across product type and time, Journal of Advertising, Vol. 36, No. 1, pp. 37-54. Hall, L., Wickham, M. (2008): Organising IMC roles and functions in the business-to-business network environment, Journal of Marketing Com- 
munications, Vol. 14, No. 3, pp. 193-206.

Hansen, G., Wenerfelt, B. (1989): Determinants of Firm Performance: The Relative Importance of Economic and Organizational Factors, Strategic Management Journal, Vol. 10; No. 5, pp. 399-411.

Herrington, D., Lollar, J., Cotter, M., Henley, J. (1996): Comparing intensity and effectiveness of marketing communications: services versus nonservices, Journal of Advertising Research, Vol. 36, pp. 61-72.

Jerman, D. (2007): Can Public Relations affect Company's Effectiveness?, in: Managing Global Transition: Globalisation, Localisation, Regionalisation, Proceedings of the $8^{\text {th }}$ International Conference of the Faculty of Management Koper University of Primorska, November 20-24, 2007, pp. 871-878.

Kitchen, P. (1999): A multi-country comparison of the drive for IMC, Journal of Advertising Research, Vol. 39, No. 1, pp. 21-38.

Kitchen, P., Schultz, D. (2003): Integrated corporate and product brand communication, Advances in Competitiveness Research, Vol. 11, No. 1, pp. $66-86$.

Kitchen, P., Schultz. D. (2009): IMC: New horizon/false dawn for a marketplace in turmoil?, Journal of marketing Communications, Vol. 15, Nos. 2-3, pp. 197-204

Kliatchko, J. (2009): The primacy of the consumer in the IMC: Espousing a personalist view and ethical implications, Journal of Marketing Communications, Vol. 15, Nos. 2-3, pp. 157-177.

Langerak F., Commandeur H.: The influence of market orientation on competitive superiority and performance of industrial business, in Proceedings $27^{\text {th }}$ EMAC Conference, Stockholm, 1998, pp. 91-105.

Le Meunier-FitzHugh, K., Lane, N. (2009): Collaboration between sales and marketing, market orientation and business performance in businessto-business organisations, Journal of Strategic Marketing, Vol. 17, Nos. 3-4, pp. 291-306.

Low, G. (2000): Correlates of Integrated Marketing Communications, Journal of Advertising Research, Vol. 40, pp. 27-39.

Damjana Jerman, Bruno Zavrsnik - MODEL OF MARKETING COMMUNICATIONS EFFECTIVENESS IN THE BUSINESS-TO-BUSINESS MARKETS 
Maltz, E., Kohli, A. (1996): Market intelligence across functional boundaries, Journal of Marketing Research, Vol. 33, pp. 47-61.

McArthur, D., Griffin, T. (1997): A Marketing Management View of Integrated Marketing Communications, Journal of Advertising Research, Vol. 37, No. 5, pp. 19-26.

McGoon, C. (1998): Cutting-edge companies use integrated marketing communication, Communication World, Vol 16, No. 1, pp. 15-20.

Mohr, J., Sohi, R. (1995): Communication flows in distribution channels: impact on assessment of communication quality and satisfaction, Journal of Retailing, Vol. 71, No. 4, pp. 393-416.

Moore, M., Fairhurst, A. (2003): Marketing capabilities and firm performance in fashion retailing, Journal of Fashion Marketing and Management, Vol. 7, No. 4, pp. 386-397.

Nowak, G., Cameron, G., Delorme, D. (1996): Beyond the world of packaged goods: assessing the relevance of integrated marketing communications for retail and consumer service marketing, Journal of Marketing Communications, Vol. 2, No. 3, pp. 173-190.

Priyanto, S. (2006): A Structural Model of Business Perfomance: An Empirical Study on Tobacco Farmers, International Journal of Business, Vol. 8, No. 1, pp. 103-134.

Rakun, M. (2002): Organizacijski vidiki integracije komuniciranja: Ali je potrebno komuniciranje integrirati?, Teorija in praksa, Vol. 39, No. 5, pp. $804-826$.

Reid, M. (2003): IMC - performance relationship: further insight and evidence from the Australian marketplace, International Journal of Advertising, Vol. 22, pp. 227-248.

Reid, M., Johnson, T., Ratcliffe, M., Skrip, K., Wilson, J. (2001): Integrated Marketing Communications in the Australian and New Zealand Wine Industry, International Journal of Advertising, Vol. 20, pp. 239 -262.

Reid, M., Luxton, S., Mavondo, F. (2005): The Relationship between integrated marketing communication, market orientation, and brand orientation, Journal of Advertising, Vol. 34, No. 4, pp. 11-23. 
Economic Research - Ekonomska Istrazivanja Vol. 25, SE 1, $2012 \quad$ Page:387

Reid, M. (2005): Performance Auditing of Integrated Marketing Communication (IMC) Actions and Outcomes, Journal of Advertising, Vol. 4, pp. 41-54

Rinallo, D., Borghini, S. (2003): A Fair(Y) Tale: The Semiotics Of B2B Communication, in The $19^{\text {th }}$ IMP conference, Lugano, 2003, 25 pp., http://www.impgroup.org/paper_view.php?viewPaper=4401, (accessed 23 September 2005)

Rust, R. et al. (2004): Measuring marketing productivity: current knowledge and future directions, Journal of Marketing, Vol. 68, pp. 76-89.

Schultz, D., Kitchen, P. (1997): Integrated marketing communications in US advertising agencies: an exploratory study, Journal of Advertising Research, Vol. 37, No. 5, pp. 7-18.

Schultz, D., Patti, C. (2009): The evolution of IMC: IMC in a customerdriven marketplace, Journal of Marketing Communications, Vol. 15, Nos. 2-3, pp. 75-84.

Smith, T., Gopalakrishna, S., Chatterjee (2006): A Three-Stage Model of Integrated Marketing Communications at the Marketing-Sales Interface, Journal of Marketing Research, Vol. 43, pp. 564-579.

Smith, T., Gopalakrishna, S., Smith, P. (2004): The complementary effect of trade shows on personal selling, International Journal of Research in Marketing, Vol. 21, pp. 61-76.

Spott, H. et al. (1998): Marketing Deja Vu: The Discovery of Integrated Marketing Communications, Journal of Marketing Education, Vol. 20, pp. 210-218.

Tosun, N. (2003): Industrial Marketing and Communications Strategies, in The $19^{\text {th }}$ IMP conference, Lugano, 2003, 15 pp.,

http://www.impgroup.org/paper_view.php?viewPaper=4431, (accessed 23 September 2005).

Wickham, M., Hall, L. (2006): An Examination of Integrated Marketing Communications in the Business-to-Business Environment: The Case of the Tasmanian Light Shipbuilding Cluster, Journal of Marketing Communications, Vol. 12, No. 2, pp. 95-108.

Damjana Jerman, Bruno Zavrsnik - MODEL OF MARKETING COMMUNICATIONS EFFECTIVENESS IN THE BUSINESS-TO-BUSINESS MARKETS 
Economic Research - Ekonomska Istrazivanja Vol. 25, SE 1, 2012 Page:388

Wilkinson, I., Young, L. (2002): Marketing in the Third Millennium: Looking Backwards and Forwards, Journal of Business Research, Vol. 55, No. 2, pp. 81-85.

Young, A., Aitken, L. (2007): Measuring marketing communications: Concentrate on outcomes, not outputs, Market Leader, B.k., pp. 51-55. Zahay, D., Griffin, A. (2004): Customer Learning Process, Strategy Selection, and Performance in Business-to-Business Service Firms, Decision Sciences, Vol. 35, No. 2, pp. 169-203.

Žabkar, V. (2007): Uèinkovitost in uspešnost trženjskega komuniciranja: primerjava primerov Effie 2002-2006, in Zbornik prispevkov 12. slovenska marketinška konferenca, Ljubljana, Ėasnik Finance, 2007, pp. 83-93. 